\title{
A Preliminary HPTLC fingerprint study of Madhuka Indica-An Immune Enhancer
}

\author{
Research Article
}

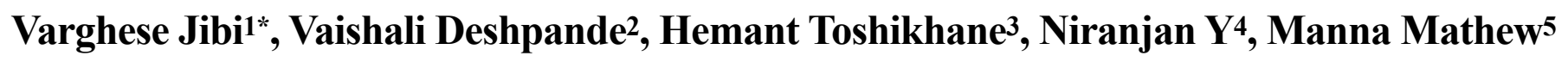

1. Ph.D. Scholar, Parul University \& Professor, Department of Kayachikitsa, 5. PG Scholar, Department of Dravyaguna,

Dr. D.Y. Patil College of Ayurved \& Research Centre, Dr. D. Y Patil Vidyapeeth ( Deemed to be University), Pimpri, Pune.

2. Professor, Department of Kayachikitsa, 3. Professor \& Dean, PIA, Parul University, Vadodara. Gujrat.

4. Professor, Department of Kayachikitsa, Indian Institute of Ayurved Research and Hospital, Rajkot.

\begin{abstract}
Ayurveda is now accepted as a global medical science. The world is shifting to herbal remedies which is considered to be safe and effective. But the quality maintenance of these herbal medicines is a difficult task which hinders the globalization of Ayurvedic drugs and it is a need to use suitable techniques to maintain relevant standards. Standardization is very much important for the reproducibility of the efficacy and safety of any drug which is brought to the counter as medicine for sale. Madhuka (1) is been mentioned in classical texts as brimhana, veerya pushtivardhana, dahahara, shramahara, vatapittavinasham, bhutadi jantudoshagna, kshatkshayharam etc. This article aims to explore the qualities of Madhuka pushpa, its HPTLC phytoconstituent fingerprint and the preliminary standardization of preparing madhuka pushpa vati for its use as an immune enhancer.
\end{abstract}

Key Words: Madhuka puspha, Immune enhancer, Veerya pushtivardhana, HPTLC

\section{Introduction}

Madhuka indica is a plant of Indian origin having tremendous therapeutic potential to provide health to the society, but it is not fully utilized and recognized. Madhuka commonly known as mahua or botanically named as madhuka indica from the sapotaceae family is a tropical tree found largely in the central and north plains and forests. Madhuka is used to prepare liquor and for fermentation process to make asava and arishtas. Madhuka pushpa has been indicated as brimhana, veerya pushtivardhana. These qualities itself indicates that madhuka has the capacity to improve all the seven dhatus or promoting the essence of all the seven dhatus (tissues) ie bringing about the Prashasta Bhava which may be equalent as an immune enhancer. Any drug may be of plant, animal or mineral origin may have varying properties as per their place of availability or climatic conditions. And hence in this present study Madhuka pushpa vati which was been prepared at a GMP certified pharmacy was subjected to standardization to maintain proper quality control, safety and efficacy of the medicine.

Aims and Objectives

1. Identification and authentification of raw drugs.

* Corresponding Author:

Varghese Jibi

Professor, Department of Kayachikitsa,

Dr. D.Y. Patil College of Ayurved \& Research

Centre, Dr. D. Y Patil Vidyapeeth (Deemed to be

University), Pimpri -Pune -18 India

Email Id: vjayu82@gmail.com
2. Preparation of Madhuka pushpa vati.

3. Phytochemical analysis and chromatography (HPTLC) of Madhuka pushpa vati.

\section{Materials and Methods}

Collection of raw drugs

The raw drugs were procured from Udupi, Karnataka. The part used are given in the table No 1. The raw drug was identified as Madhuka indica belonging from Sapotaceae family which was certified from SDM Centre for Research in Ayurveda and Allied sciences, Udupi, Karnataka.

\begin{tabular}{|c|c|c|c|c|}
\multicolumn{5}{|c}{ Table No. 1 } \\
$\begin{array}{c}\text { Sr. } \\
\text { No. }\end{array}$ & $\begin{array}{c}\text { Name of } \\
\text { Drug }\end{array}$ & Latin Name & Family & $\begin{array}{c}\text { Part } \\
\text { used }\end{array}$ \\
\hline 1 & Madhuka & $\begin{array}{c}\text { Madhuka } \\
\text { indica }\end{array}$ & Sapotaceae & Flowers \\
\hline
\end{tabular}

Vernacular names $(2,3,4)$

- Sanskrit : Madhuka

- Classical name : Madhuka

- English : Indian butter tree

- Hindi : Mahua

Taxonomical position -

- Kingdom : Plantae

- Division : Magnoliophyta

- Subdivision : Angiosperm

- Class : Magnoliopsida

- Subclass : Caesalpinieace

- Order : Ericaleae

- Family : Sapotaceae

- Genus : Madhuka

- Species : indica, longifolia 


\begin{tabular}{|c|c|}
\hline & Varghese Jibi et.al., A Preliminary HPTLC fingerpro \\
\hline Guna & Madhuka \\
\hline Rasa & Madhura Kashaya \\
\hline Veerya & Sheeta \\
\hline Vipaka & Madhura \\
\hline Guna & Snigdha, guru \\
\hline Dosha & Vata pitta hara \\
\hline Karma & Brimhanam, Shukrakruta, Veerya pushti \\
& vivardhanam \\
\hline
\end{tabular}

\section{Methods of evaluation}

Microscopy of Madhuka pushpa and HPTLC of Madhuka pushpa vati was analyzed by using standard qualitative and quantitative parameters. All the procedures were conducted at Sri Dharmasthala Manjunatheswara Centre for Research in Ayurveda and Allied sciences (AYUSH centre for Excellence and Recognized SIROs by DSIR)

\section{Macroscopy}

The external features of the test samples were documented using Canon IXUS digital camera. The macroscopic features of Madhuka indica were compared to local flora for authentication.

\section{Figure 1: Macroscopy of Madhuka indica flower}

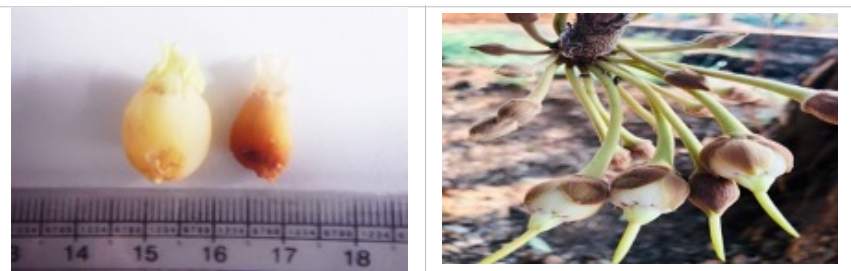

Madhuka indica flower

\section{Microscopy Study}

Sample was preserved in fixative solution. The fixative used was FAA (Formalin-5ml + Acetic acid- $5 \mathrm{ml}+70 \%$ Ethyl alcohol-90ml). The materials were left in FAA for more than 48 hours. The preserved specimens were cut into thin transverse section using a sharp blade and the sections were stained with saffranine. The slides were also stained with iodine in potassium iodide for detection of starch. Transverse sections were photographed using Zeiss AXIO trinocular microscope attached with Zeiss AxioCam camera under bright field light. Magnifications of the figures are indicated by the scale-bars.

\section{Description of flower}

\section{Macroscopic characters of flowers from Fig. 1}

Drug consists of mostly corolla and androecium; corolla fleshy, reddish -brown, tubular, lobes 7-14(usually 8-9), ovate lanceolate, short, erect $0.5-2 \mathrm{~cm}$ long; Stamensepipetalous, basifixed, lanceolate, pointed at tip and hairy at the back with prominent dark brown connective strand; Taste-sweet. Figure 2: Microscopy of Madhuka Indica flower.

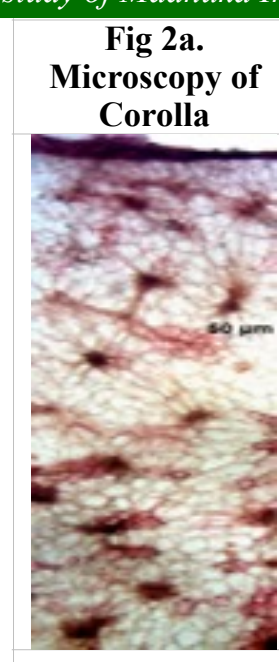

Fig 2d.

Vascular bundle

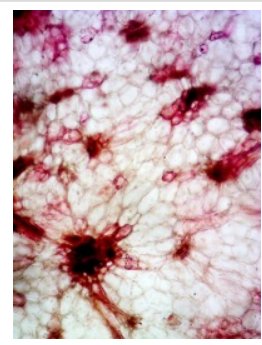

OE - Outer epidermis, $\mathrm{Pa}$-Parenchymatous cell, VBVascular Bundle, IE- Inner epidermis

\section{Microscopy of Madhuka flower from Fig. 2a -2f: Corolla}

Petal shows a single layered epidermis, followed by thin-walled, irregularly shaped parenchymatous cells; vascular bundles found scattered in parenchymatous tissues.

\section{Androecium}

Anther shows 4 pollen chambers and prominent cells of connective tissue in the centre of the chambers; epidermis single layered covered with thin cuticle; a few unicellular hairs present on one side; endothecium composed of radially elongated, oval shaped lignified cells; tapetum not distinct; pollen grains single or in groups, spherical, with clear exine and entine walls scattered in the pollen sac, a few cells of the vascular bundles are seen embedded in the connective tissues.

\section{Standardisation of Madhuka pushpa vati}

- Preparation of Madhuka pushpa vati: It was prepared in S.D.M College of Ayurveda pharmacy , Udupi.

- Method: Madhuka pushpa initially it was tray dried for 3-4 days. Later it was kept in dryer for 7-8 days with 48-50 degree Celsius under $760 \mathrm{~mm}$ of $\mathrm{Hg}$ pressure and later it was made into vati without using any binding agent. Each vati in the batch measured nearly 3 grams with a hardness test of 1.0 $\mathrm{kg} / \mathrm{cm}$ and disintegration time of 39 minutes. The prepared vati was solid with a shiny black appearance, sweet astringent in taste with a mild aroma. The results are depicted in table no $2 \& 3$ and the final product after making of vati is depicted in Figure no 3. 
Table no 2. - Results of Standardization of Madhuka pushpa vati

\begin{tabular}{|l|c|}
\multicolumn{1}{c|}{ Parameters } & Madhuka pushpa vati \\
\hline Tablet average wt & 3.087 \\
\hline $\begin{array}{l}\text { Tablet average } \mathrm{wt} \\
\text { (Average } \mathrm{w} t \mathrm{SEM})\end{array}$ & $3.087 \pm 0.16$ \\
\hline Variation in weight $(\%)$ & 0.16 \\
\hline Hardness test $(\mathrm{kg} / \mathrm{cm})$ & 1.0 \\
\hline Disintegration time $(\mathrm{min})$ & 39
\end{tabular}

Table no 3. - Organoleptic characteristics of Madhuka pushpa vati

\begin{tabular}{|l|l|}
\multicolumn{1}{|c|}{ Character } & Observation \\
\hline Color & Black \\
\hline Odour & Aromatic \\
\hline Taste & Sweet, Astringent \\
\hline Consistency & Solid \\
\hline
\end{tabular}

Figure No. 3 - Preparation of Madhuka pushpa vati
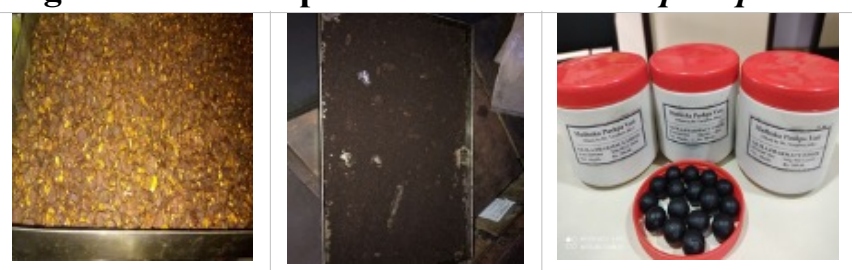

\section{HPTLC study}

Madhuka pushpa vati was subjected to HPTLC study at Sri Dharmasthala Manjunatheswara Centre for Research in Ayurveda and Allied sciences (AYUSH centre for Excellence and Recognized SIROs by DSIR) and the results with photo documentation after derivatisation is depicted in Figure 4 using linomat 5 applicator, CAMAG visualization chamber and CAMAG scanner 4 with wincats software.

Figure 4: HPTLC Photodocumentation of sample of Madhukapushpa Vati

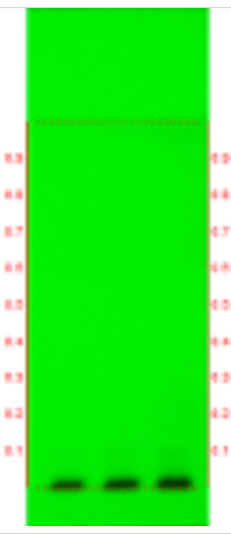

Short UV

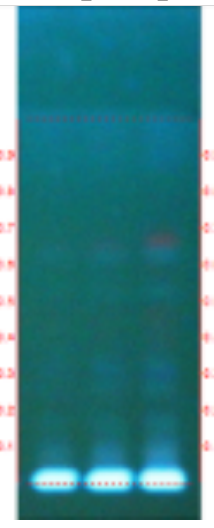

Long UV

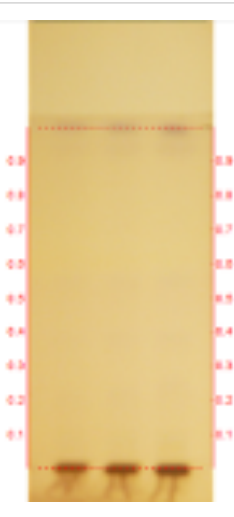

After derivatisation
Track 1: Madhukapushpa vati- $3 \mu 1$

Track 2: Madhukapushpa vati- $6 \mu 1$

Track 3: Madhukapushpa vati- $9 \mu 1$

Solvent system- Toluene: Ethyl acetate (7.0: 1.0)
Table 4: Rf values of sample Madhuka Pushpa vati

\begin{tabular}{l|l|l} 
Short UV & Long UV & After derivatisation
\end{tabular}

0.08 (F. blue)

0.19 (F. blue)

0.27 (F. blue)

0.34 (F. blue)

0.53 (F. blue)

0.63 (F. blue)

0.67 (F. red)

Figure 5: Densitometric scan of the sample of Madhukapushpa vati
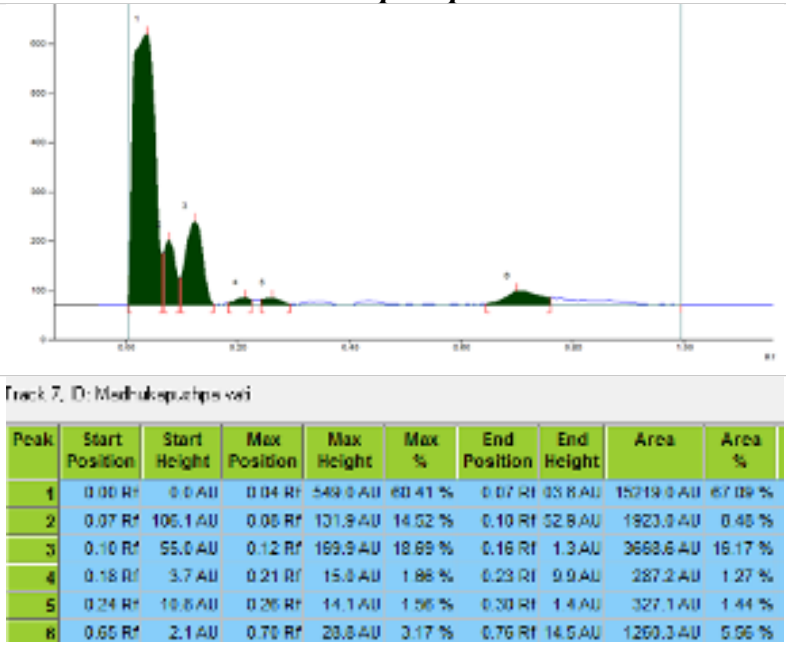

Fig 5a. At 254nm

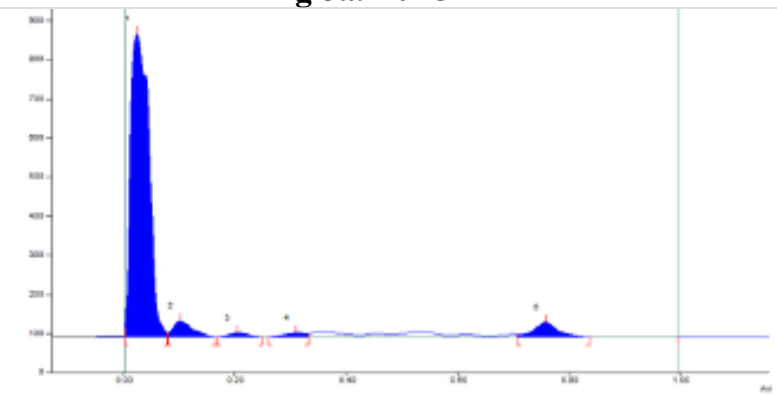

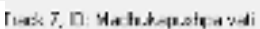

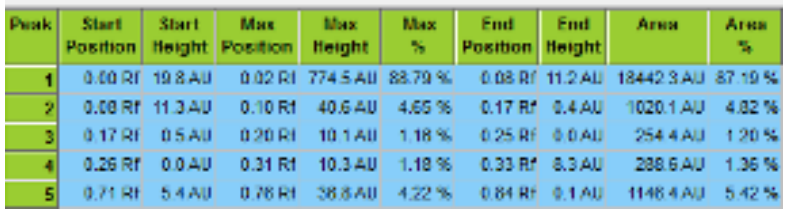

Fig 5b. At 366nm

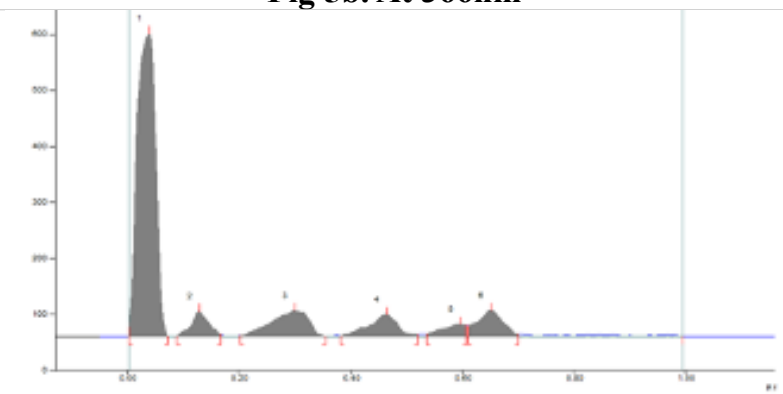

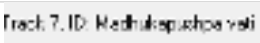

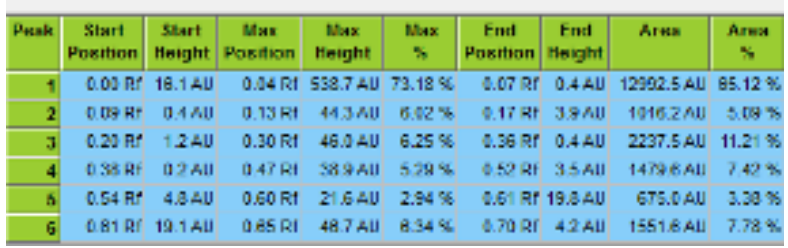

Fig 5c. At 620nm 


\section{Results on HPTLC of Madhuka pushpa vati}

HPTLC plate was applied with ethanolic extract of sample at $3,6,9 \mu 1$ with linomat 5 applicator, was developed in Toluene: Ethyl acetate (7:1) solvent system and the developed plates following drying were observed in CAMAG visualization chamber followed by scanning at $254 \mathrm{~nm}, 366 \mathrm{~nm}, 620 \mathrm{~nm}$ using CAMAG scanner 4. After derivatization, plate was examined for appearance of different bands at different $R_{f}$ and following were the findings

1. Madhukapushpa vati at Short UV shows no bands; at long UV it shows 7 bands with $R_{\mathrm{f}}$ at $0.08,0.19$, $0.27,0.34,0.53,0.63,0.67$, after derivatization with ASA (anisaldehyde sulphuric acid) reagent there were no bands prominently evident.

2. At $254 \mathrm{~nm}$ desnsitometric scan shows 6 peaks at $\mathrm{R}_{\mathrm{f}}$ $0.04(67.09 \%), 0.08$ (8.48\%), 0.12 (16.17\%), 0.21 $(1.27 \%), 0.26(1.44 \%), 0.70(5.56 \%)$ among which notable one was $0.12(16.17 \%)$. At $366 \mathrm{~nm}$ densitometric scan shows 5 peaks at $\mathrm{R}_{\mathrm{f}} 0.02,0.10$, $0.20,0.31,0.76$ among which major peaks were at $0.10(4.82 \%), 0.76(5.42 \%)$. At $620 \mathrm{~nm}$ (Following derivatisation with Anisaldehyde sulphuric acid reagent) 6 peaks were depicted among which $0.30(11.21 \%), 0.65(7.78 \%)$ were prominent.

Thus, Madhuka pushpa vati was found to be rich in phytoconstituents.

\section{Conclusion}

Madhuka indica with madhura rasa, snigdha guru guna and sheeta veerya madhura vipaka is indicated as brimhana, shukrakara and vatapitta shamaka. Hence it is said to improve the body tissues, specifically shukra dhatu as the panchabhautika guna of madhuka pushpa and shukra is similar and therefore improving the ojus or immunity. Madhuka pushpa vati were analysed with organoleptic characters, phytochemical parameters and chromatographic study. Standard quality techniques of Vati kalpana were adopted in making of Madhuka pushpa vati. In future for further exploration of Madhuka indica this study will helpful to prepare a monograph for Ayurvedic Formulary of India (AFI).

\section{References}

1. Bhrahmasankara Mishra, Sri Rupalalaji Vaisya, Bhavprakasha of Sri Bhavamishra, Hindi commentary, Chaukhambha Sanskrit Sansthan, Varanasi, Second Part, 9 $9^{\text {th }}$ edition, Pg no 579

2. The Wealth of India Vo-6, 1st published by Council of Scientific and industrial research, New Delhi, Reprint 1998: Pp-482, pg no.207-216

3. Nadkarni K.M. Indian Materia Medica. 3rd ed. volume I. Mumbai: Popular Prakashan Private Limited; Pp-1319., Pg No-178-182

4. Government of India, The Ayurvedic Pharmacopiea of India. 1st edition, Reprint. New Delhi. The Controller of Publications Civil Lines; 2008; Part I. Vol -11 Pp-368 Pg no-102-103

5. Government of India, The Ayurvedic Pharmacopiea of India. 1st edition, Reprint. New Delhi. The Controller of Publications Civil Lines; 2008; Part I. Vol -11 Pp-368 Pg no-102-103. 